\title{
Do food standards affect the quality of EU imports?
}

\author{
Alessandro Olper ${ }^{\mathrm{a}, \mathrm{b}, *}$, Daniele Curzi ${ }^{\mathrm{a}}$, Lucia Pacca ${ }^{\mathrm{a}}$

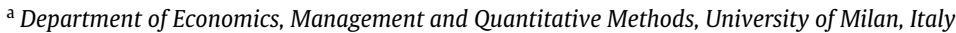 \\ ${ }^{\mathrm{b}}$ LICOS - Centre for Institutions and Economic Performance, Belgium
}

\section{H I G H L I G H T S}

- We study the relation between the diffusion of food standards and the quality of EU imports.

- We find that on average, the diffusion of standards boosts the rate of quality upgrading.

- We find heterogeneity considering primary vs. processed products and ISO vs. non-ISO standards.

\section{A R T I C L E I N F O}

\section{Article history:}

Received 30 July 2013

Received in revised form

19 November 2013

Accepted 24 November 2013

Available online 4 December 2013

\section{JEL classification:}

C23

F13

F14

L15

014

Q17

\section{Keywords:}

Quality upgrading

EU food standards

Competition

Distance to the frontier

\begin{abstract}
A B S T R A C T
This paper investigates the relationship between the diffusion of EU standards and product quality upgrading using highly disaggregated import data to the EU in the food industry. Results show that, on average, the diffusion of EU voluntary standards boosts the rate of quality upgrading. However, the results are heterogeneous when moving from primary to processed foods, and from ISO to non-ISO standards.
\end{abstract}

(C) 2013 Elsevier B.V. All rights reserved.

\section{Introduction}

Food standards increasingly govern international food supply chains. Beside mandatory public standards (established by governments), voluntary ones (set by private organizations) are becoming increasingly important in global agri-food chains. These standards may relate to food safety and the integrity of food safety systems, but can also refer to aspects of food such as provenance,

\footnotetext{
Financial support from the European Commission FP7 Project "Compete" (Grant agreement no: 312029 ) is gratefully acknowledged.

* Corresponding author at: Department of Economics, Management and Quantitative Methods, University of Milan, Italy. Tel.: +39 0250318481; fax: +39 0250318486

E-mail address: alessandro.olper@unimi.it (A. Olper).
}

environmental impact, and animal welfare. ${ }^{1}$ Voluntary standards can be either set at the international level or by collective organizations which operate within the boundary of a country (or groups countries, as in the case of the EU), including industry associations and non-governmental organizations. Concerning standards in general, one of the most studied issue is their impact on international trade. Standards could either act as non-tariff barriers to trade - constituting impediments to countries' exports - or as catalysts to trade - leading to export gains, by modernizing the food

\footnotetext{
1 Examples of EU standards related to food safety and quality are the ones referred to the traceability in the feed and food chain (ISO 22005), and some standards at the product level like EN 14104 on the acid value of fat and oil derivatives or EN ISO 1211 on the fat content of milk. As for the other products' characteristics, it is worth citing the voluntary standard related to products' ecolabeling (EN ISO 14020) and the one on animal welfare (RSPCA Freedom Food).
} 
supply chains through innovation and products' upgrading (Swinnen, 2007). Studies focusing on public standards, such as sanitary and phytosanitary measures (SPS), in most cases find that they act as non-tariff barriers to trade (Olper and Raimondi, 2008; Li and Beghin, 2012). On the contrary, studies based on voluntary standards often conclude that they have a positive effect on the intensity of trade flows, at least when harmonized standards and North-North trade are considered. There are, however, several exceptions (see Blind and Jungmittag, 2005; Swann, 2010; Shepherd and Wilson, 2013).

Empirically, the trade effect of food standards has been largely studied within the gravity model framework. However, little attention has been paid so far to the direct quantification of the relationship between the diffusion of standards and the rate of exports' quality upgrading. This is quite surprising, especially because the enhancement of traded products is at the heart of the hypothesis on standards as a catalysts to trade (Maertens and Swinnen, 2009; Henson et al., 2011).

In this paper, we provide the first broad formal evidence that the diffusion of (voluntary) standards within the export destination market systematically affects the rate of quality upgrading of the imported food products. To this end, we use highly disaggregated data on exports from about 70 countries to the European Union (EU) for more than 2000 food products. Product quality is inferred from trade data, using an approach recently developed by Khandelwal (2010).

Since quality upgrading represents a form of innovation, our empirical exercise is carried out within the 'distance to the frontier' framework of Aghion et al. (2005). This model, which investigates the relation between competition and innovation, has been recently borrowed by Amiti and Khandelwal (2013) to study the impact of import tariffs on quality upgrading. According to Aghion et al. (2005), an increase in competition induces firms (sectors) that are initially close to the technology frontier to innovate more, while it reduces the expected rents from innovation for firms (sectors) further away from the frontier. The interplay between these two forces induces a relationship between competition and innovation that is non-monotonic and conditional to the firm/industry distance from the technology frontier. In this context, the effect of standards on quality upgrading should depend on the pro- or anticompetitive effect of standards. As the effect of standards on trade and competition is theoretically ambiguous, this relationship is an empirical open question.

\section{Conceptual framework and the empirical model}

According to the literature, standards can have anti-competitive or pro-competitive effects. From this perspective, at least two main hypotheses can be formulated (Blind and Jungmittag, 2005).

First, as discussed in Leland (1979), Hudson and Jones (2003) and many others, standards can serve as an important quality signal in trade and thus can make a major contribution to enhancing products' competitiveness. Evidence that food standards can stimulate competitiveness can be found in Maertens and Swinnen (2009) and Henson et al. (2011). Moreover, standards can help to overcome the 'lemons' problem, namely the fact that incomplete and asymmetric information on the quality of products can lead to market failures and to a reduction in average products' quality (Leland, 1979). Under this hypothesis, the distance to the frontier model should predict that the diffusion of standards boosts quality upgrading in the leading firms/sectors, while hinders it in laggard firms/sectors.

However, standards may also have negative effects, as they can raise barriers to entry especially through their high compliance costs. Indeed, while in principle standards can be considered as a public good which every producer can use, in practice, due to their high adaptation costs, complying to them is difficult and disadvantageous for outsiders with no influence on the standardization process (Blind and Jungmittag, 2005; Swann, 2010). Moreover, a peculiarity of many food standards is the fact that they are often driven by the preferences of consumers, as for the case of GMOs standards (Vigani et al., 2012). More in general, the anticompetitive effects of standards may derive, intentionally or unintentionally, from the national political process (Fischer and Serra, 2000; Swinnen and Vandemoortele, 2011). To the extent to which standards are protectionist, the distance to the frontier model predicts a negative relation between their diffusion and the rate of quality upgrading, especially for firms and products which are close to the quality frontier.

Empirically, the two concurrent hypotheses summarized above can be tested following Amiti and Khandelwal (2013). Let $D F_{\text {hit }}$ be the distance to the frontier of variety $h c$ (product $h$ exported by country $c$ ) imported by the EU country $i$ at time $t$, namely the ratio of its quality to the highest quality within the same product category (CN 8-digit). ${ }^{2}$ Our strategy is aimed at testing the following empirical model:

$$
\begin{aligned}
\Delta \ln \lambda_{\text {hcit }}= & \beta_{1} D F_{h c i t-5}+\beta_{2} S T D_{h t-5}^{e u} \\
& +\beta_{3}\left(D F_{h c i t-5} * S T D_{h t-5}^{e u}\right)+\gamma_{i} X_{h c t-5}+\varepsilon_{h c i t} .
\end{aligned}
$$

The dependent variable, $\Delta \ln \lambda_{\text {hcit }}^{F}$, is the change in a variety's quality between period $t$ and $t-5$. All the explanatory variables are lagged of five years. Quality growth is explained by the lagged proximity to the frontier $\left(D F_{h c i t-5}\right)$, the $(\log )$ lagged number of EU standards $\left(S T D_{h t-5}^{e u}\right)$ and the interaction term between these two variables $\left(D F_{h c i t-5} * S T D_{h t-5}^{e u}\right)$. This interaction term allows for the possible non-monotonic relationship stressed by the distance to the frontier theory. Finally, $X_{h c t-5}$ are controls for exporting countries characteristics. The error term, $\varepsilon_{\text {hcit }}=\alpha_{h i}+\alpha_{c t}+$ $\sigma_{\text {hcit }}$, includes both importer country-product $\left(\alpha_{h i}\right)$ and exporter country-year $\left(\alpha_{c t}\right)$ fixed effects, plus an identically distributed idiosyncratic error $\left(\sigma_{\text {hcit }}\right)$. $^{3}$

\section{Quality estimate and the data}

To estimate quality we replicate the procedure in Khandelwal (2010) on the EU markets, based on the following equation:

$$
\begin{aligned}
\ln \left(s_{\text {hcit }}\right)-\ln \left(s_{0 i t}\right)= & \lambda_{1, h c i}+\lambda_{2, i t}+\alpha p_{\text {hcit }} \\
& +\sigma \ln \left(n s_{\text {hcit }}\right)+\lambda_{3, \text { hcit }},
\end{aligned}
$$

where $s_{\text {hcit }}$ is the market share of variety $h c$ imported by the EU country $i$ in year $t$, and $s_{0 i t}$ is the market share of the domestic production. On the right-hand side, $\lambda_{1, h c i}$ is the variety $h c$ fixed effect, $\lambda_{2, t}$ is the time effect, and $\lambda_{3, h c i t}$ is the residual. Other righthand side variables are the price of the variety $h c, p_{\text {hcit }}$, and the (nest) share of variety $h c$ in total imports for the CN-8 category $h, n s_{\text {hit }}$.

We estimate Eq. (2) separately for each NACE 4-digit industry and for all the considered importing countries $i$ (the EU-15 members). The estimation is carried out by using 2SLS, to account for the potential correlation of the error term, $\lambda_{3, h i t}$, with both the

\footnotetext{
2 Varieties' distance to the frontier is thus estimated as follows: $D F_{\text {hcit }}=$ $\frac{\lambda_{\text {hit }}}{\max _{c \in \text { hit }}\left(\lambda_{\text {hcit }}\right)}$. Note that, for varieties close to the frontier $D F_{\text {hcit }}$ will be close to 1 , while for varieties far from the frontier $D F_{h c i t}$ will be close to 0 .

3 Quality is estimated using a nested logit demand function within each 4 digit country/industry separately (see Section 3); the country-product fixed effects ensure that the estimation only exploits the variation between comparable quality estimates. The country-year fixed effects sweep out country-level shocks that affect competition such as technological shocks, changes in relative endowment, changes in institutions that affect competition.
} 
Table 1

Quality, competition and standards: baseline results.

\begin{tabular}{|c|c|c|c|c|}
\hline & \multicolumn{2}{|c|}{ All products } & \multirow{2}{*}{$\begin{array}{l}\text { Primary } \\
(3)\end{array}$} & \multirow{2}{*}{$\begin{array}{l}\text { Processed } \\
\text { (4) }\end{array}$} \\
\hline & (1) & $(2)$ & & \\
\hline Lagged ln standard $(t-5)$ & $\begin{array}{l}0.158^{* * *} \\
(0.032)\end{array}$ & $\begin{array}{l}0.158^{* * * *} \\
(0.032)\end{array}$ & $\begin{array}{l}-0.188^{* * * *} \\
(0.046)\end{array}$ & $\begin{array}{l}0.198^{* * * *} \\
(0.039)\end{array}$ \\
\hline Lagged ln standard ${ }^{*}$ distance to the frontier $(t-5)$ & $\begin{array}{l}-0.0090 \\
(0.006)\end{array}$ & $\begin{array}{l}-0.010^{*} \\
(0.006)\end{array}$ & $\begin{array}{l}-0.040^{*} \\
(0.022)\end{array}$ & -0.005 \\
\hline Lagged distance to the frontier $(t-5)$ & $\begin{array}{l}-0.503^{* * *} \\
(0.037)\end{array}$ & $\begin{array}{l}-0.458^{* * * *} \\
(0.042)\end{array}$ & $\begin{array}{l}-0.394^{* * *} \\
(0.059)\end{array}$ & $\begin{array}{l}-0.470^{* * *} \\
(0.046)\end{array}$ \\
\hline Lagged tariffs $(t-5)$ & & $\begin{array}{l}0.077^{* *} \\
(0.029)\end{array}$ & $\begin{array}{l}0.141^{* *} \\
(0.067)\end{array}$ & $\begin{array}{l}0.067^{* *} \\
(0.028)\end{array}$ \\
\hline Lagged tariffs $*$ distance to the frontier $(t-5)$ & & $\begin{array}{l}-0.183^{* * * *} \\
(0.047)\end{array}$ & $\begin{array}{l}-0.342^{* * * *} \\
(0.111)\end{array}$ & $\begin{array}{l}-0.173^{* * *} \\
(0.052)\end{array}$ \\
\hline Importer-product fixed effects & YES & YES & YES & YES \\
\hline Exporter-year fixed effects & YES & YES & YES & YES \\
\hline Observations & 226485 & 226485 & 31072 & 195413 \\
\hline$R-\mathrm{sq}$ & 0.230 & 0.230 & 0.230 & 0.232 \\
\hline
\end{tabular}

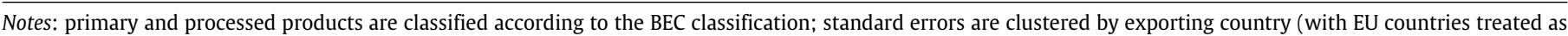
one country because of its common trade policy).

* Significance 0.10

** Significance 0.05 .

Significance 0.01

variety's price and the nest share. Following Khandelwal (2010) and Colantone and Crinò (2013), price is instrumented by the interaction between unit transportation costs and the distance from $c$ and by the interaction between the oil price and the distance from $c$; differently, the nest share is instrumented by the number of varieties exported within the nest and the overall number of varieties exported by each trading partner to the EU.

The quality of variety $h c$ imported by the EU country $i$ at time $t, \hat{\lambda}_{\text {hcit }}$, is then obtained by:

$\hat{\lambda}_{\text {hcit }}=\hat{\lambda}_{1, h c i}+\hat{\lambda}_{2, t}+\hat{\lambda}_{3, h c i t}$.

When implementing this procedure, we follow closely Khandelwal (2010) and Colantone and Crinò (2013), which may be consulted for further details. Differently, for a description and discussion of the quality estimates and details of the data used, see Curzi et al. (2013).

We collect data on European standards from the European Union Standard Database (EUSDB). EUSDB provides data on voluntary standards in force in the European Union from 1995 to 2003. Data are mapped according to the standard trade HS 4-digit classification. EUSDB includes only standards at the community level, hence excluding national standards set by individual member states. The EUSDB database also provides information on whether or not a particular EU standard implements a corresponding international harmonized, ISO, standard (see Shepherd, 2007, for further details). ${ }^{4}$ In order to control for the level of competition that the exporters face in their own country and industry, we use as additional control the ad valorem tariffs, as in Amiti and Khandelwal (2013). We collect these data from WITS, at the HS 6-digit level and over time.

\section{Results}

Table 1 reports our baseline results about the effect of standards on quality upgrading. Column 1 shows that the estimated coefficient of standards is positive and strongly significant for the linear term, and negative but insignificant for the interaction with the

\footnotetext{
4 ISO standards, unlike non-ISO ones, are developed and approved by the International Standards Organization and supported worldwide. Among the most popular standards within this category, there are the ISO 9000 family about quality management and the ISO 14000 one which addresses the Environmental Management.
}

distance to the frontier variable. Quantitatively, the magnitude of the economic effect is quite important. A $10 \%$ increase in the number of standards, on average, induces an increase in the rate of quality upgrading of about $1.6 \%$. Moreover, the negative coefficient of the lagged proximity to the frontier suggests that varieties far from the frontier, on average, display a faster rate of quality upgrading.

Column 2 adds to the specification the exporters' level of tariff and its interaction with the distance to the frontier. A positive coefficient on the linear tariff and a negative coefficient on the interaction term imply that varieties close to the world frontier are more likely to upgrade quality in response to an increase in competition (tariffs reduction), while the opposite holds for varieties far from the frontier. This result is in line with what Amiti and Khandelwal (2013) find on the US market, thus giving support to the distance to the frontier framework. However, more importantly for our purpose, when controlling for tariffs the effect of standards on quality upgrading holds virtually unaffected, though it decreases marginally for varieties close to the frontier. In addition to this, our results allow us to compare the marginal effect of tariffs with that of standards: while the former is clearly non-monotonic, the latter holds positive both for varieties far and close to the frontier, although at a decreasing rate.

Next, because the anti- or pro-competitive effects of standards can depend on the type of product involved, an interesting question is whether the results discussed above are heterogeneous when considering primary vs. processed foods. Indeed, some evidence from the literature suggests that the negative trade effects of food standards could be more severe for primary than for processed food products (Shepherd and Wilson, 2013; Li and Beghin, 2012). These findings are confirmed by our results. First, considering primary products (column 3 ) the effect of standards turns out to be significantly negative, and more so for varieties close to the frontier. On the other hand, considering processed foods (column 4) the effect is positive and stronger in magnitude with respect to the whole sample. This appears in line with the idea that processed foods are more differentiable than primary ones. Although the results on the whole sample hide this differentiated effect of standards, it is clear that the overall positive results are driven by processed products which represent about $86 \%$ of the observations in our sample. ${ }^{5}$

\footnotetext{
5 All the results in Table 1 hold and are robust even when splitting the sample in OECD and non-OECD exporting countries. These additional results are available upon request.
} 
Table 2

Quality, competition and standards: ISO vs. non-ISO standards.

\begin{tabular}{|c|c|c|c|}
\hline & $\begin{array}{l}\text { All countries } \\
(1)\end{array}$ & $\begin{array}{l}\text { OECDs } \\
(2)\end{array}$ & $\begin{array}{l}\text { Non-OECDs } \\
\text { (3) }\end{array}$ \\
\hline Lagged ln ISO standard $(t-5)$ & $\begin{array}{l}-0.055^{* * * *} \\
(0.011)\end{array}$ & $\begin{array}{l}-0.059^{* * * *} \\
(0.012)\end{array}$ & $\begin{array}{l}-0.039 \\
(0.029)\end{array}$ \\
\hline Lagged ln ISO standard ${ }^{*}$ distance to the frontier $(t-5)$ & $\begin{array}{l}-0.028^{* *} \\
(0.012)\end{array}$ & $\begin{array}{l}-0.027^{*} \\
(0.014)\end{array}$ & $\begin{array}{l}-0.032 \\
(0.037)\end{array}$ \\
\hline Lagged ln non-ISO standard $(t-5)$ & $\begin{array}{l}0.183^{* * *} \\
(0.029)\end{array}$ & $\begin{array}{l}0.185^{* * *} \\
(0.031)\end{array}$ & $\begin{array}{l}0.180^{* * *} \\
(0.032)\end{array}$ \\
\hline Lagged ln non-ISO standard ${ }^{*}$ distance to the frontier $(t-5)$ & $\begin{array}{l}-0.002 \\
(0.008)\end{array}$ & $\begin{array}{l}-0.005 \\
(0.009)\end{array}$ & $\begin{array}{l}0.008 \\
(0.031)\end{array}$ \\
\hline Lagged distance to the frontier $(t-5)$ & $\begin{array}{l}-0.472^{* * * *} \\
(0.048)\end{array}$ & $\begin{array}{l}-0.483^{* * *} \\
(0.048)\end{array}$ & $\begin{array}{l}-0.380^{* * * *} \\
(0.113)\end{array}$ \\
\hline Lagged tariffs $(t-5)$ & $\begin{array}{l}0.055 \\
(0.033)\end{array}$ & $\begin{array}{l}0.032 \\
(0.028)\end{array}$ & $\begin{array}{l}0.139^{* *} \\
(0.056)\end{array}$ \\
\hline Lagged tariffs * distance to the frontier $(t-5)$ & $\begin{array}{l}-0.178^{* * * *} \\
(0.051)\end{array}$ & $\begin{array}{l}-0.158^{* * *} \\
(0.047)\end{array}$ & $\begin{array}{l}-0.226^{*} \\
(0.129)\end{array}$ \\
\hline Importer-product fixed effects & YES & \multicolumn{2}{|c|}{ YES } \\
\hline Exporter-year fixed effects & YES & \multicolumn{2}{|c|}{ YES } \\
\hline Observations & 226485 & \multicolumn{2}{|c|}{226485} \\
\hline$R-\mathrm{sq}$ & 0.230 & \multicolumn{2}{|c|}{0.230} \\
\hline
\end{tabular}

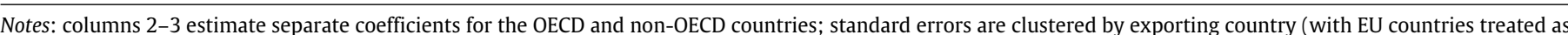
one country because of its common trade policy).

* Significance 0.10 .

** Significance 0.05 .

**** Significance 0.01 .

A second issue raised in the literature suggests that the effect of standards could be heterogeneous when considering ISO vs. nonISO standards, as well as the level of countries' development (Blind and Jungmittag, 2005; Czubala et al., 2009; Shepherd and Wilson, 2013). In Table 2 we study these hypotheses in depth. In column 1 , when comparing ISO and non-ISO standards, the effect on the rate of quality upgrading is the opposite, namely significantly negative for ISO standards (and increasing so when approaching to the frontier) and significantly positive for non-ISO standards (no matter the distance to the frontier). Note, moreover, that the (absolute) magnitude of the economic effect for non-ISO standards is more than three times higher. In addition to this, when splitting these effects according to the different level of development of exporting countries (OECDs vs. non-OECDs), the main results hold except for the ISO standards effect on developing countries, which is still negative but lower in magnitude and not significant. ${ }^{6}$

The different effect on quality upgrading which emerges when moving from ISO to non-ISO standards may appear counterintuitive at first glance. However, since our product quality measure is implicitly driven by the market share in the destination country, after controlling for price (see Section 3), these results come as no surprise. Indeed, one should consider that complying with the EU non-ISO standards could represent a valuable strategy to increase the market share in such a demanding market. By contrast, the negative effect of ISO standards, even if small in magnitude, makes sense if one considers their characteristics. First, as the result of an international harmonization process, ISO-standards tend to be less demanding in terms of compliance requirements. Second, they can lead to a reduction of product diversity and thus slow down the incentives for intra-industry trade (Blind and Jungmittag, 2005). The finding that ISO standards affect negatively the quality upgrading for trade coming from OECDs, but not for non-OECDs, gives credence to this interpretation.

\footnotetext{
6 The results presented above are robust to the following robustness checks: different definitions of the quality frontier (e.g. excluding the top quality and the top two quality products; using as an alternative quality measure the percentile of a variety's quality within each product-year pair); controlling for the (EU15) import tariffs; different combinations of product, country and year dummies; heterogeneity effect according to institutional variables. These additional results are available from the authors upon request.
}

\section{Conclusions}

In this paper we provide evidence that the effect of the diffusion of EU food standards on the rate of quality upgrading is, on average, positive and largely driven by non-ISO standards and processed foods. At the same time, we showed that the effect of food standards, unlike that of tariffs, does not depend on the varieties' distance to the quality frontier. Indeed, although a nonmonotonic relation comes out from the data, the marginal effect of standards is overall positive both for varieties close and far from the frontier. Thus, from this perspective, our results confirm the mixed effects of standards on competition.

However, we want to stress that the average positive effect of EU standards on exports quality upgrading of both developed and developing countries is a new finding, in sharp contrast with much of the gravity literature that often highlighted the barrier to trade effect of standards. Clearly, these two results are not strictly comparable, because they focus on two different concepts, namely quality upgrading in trade vs. trade flows per se. However, to the extent to which the quality of exported products matters for the firms' export performance, as a large and growing literature suggests, these findings may have interesting trade and welfare implications.

\section{References}

Aghion, P., Bloom, N., Blundell, R., Griffith, R., Howitt, P., 2005. Competition and innovation: an inverted U relationship. Q. J. Econ. 120 (2), 701-728.

Amiti, M., Khandelwal, A.K., 2013. Import competition and quality upgrading. Rev. Econ. Stat. 95 (2), 476-490.

Blind, K., Jungmittag, J., 2005. Trade and the impact of innovations and standards: the case of germany and the UK. Appl. Econ. 37 (12), 1385-1398.

Colantone, I., Crinò, R., 2013. New imported inputs, new domestic products. J. Int. Econ., http://dx.doi.org/10.1016/j.jinteco.2013.10.006.

Curzi, D., Raimondi, V., Olper, A., 2013. Quality upgrading, competition and trade policy: evidence from the agri-food sector. In: Paper presented at IATRC 2013 Symposium Productivity and Its Impacts on Global Trade, 2-4 June, 2013, Seville, Spain.

Czubala, B., Shepherd, B., Wilson, J.S., 2009. Help or hindrance? The impact of harmonised standards on African exports. J. Afr. Econ. 18 (5), 711-744.

Fischer, R., Serra, P., 2000. Standards and protection. J. Int. Econ. 52 (2), 377-400.

Henson, S., Masakure, O., Cranfield, J., 2011. Do fresh produce exporters in sub-Saharan Africa benefit from globalgap certification? World Dev. 39 (3), 375-386. 
Hudson, J., Jones, P., 2003. International trade in 'quality goods': signaling problems for developing countries. J. Int. Dev. 15 (8), 999-1013.

Khandelwal, A., 2010. The long and short of quality ladders. Rev. Econom. Stud. 77 (4), 1450-1476.

Leland, H.E., 1979. Quacks, lemons, and licensing: a theory of minimum quality standards. J. Polit. Economy 87 (6), 1328-1346.

Li, Y., Beghin, J.C., 2012. A meta-analysis of estimates of the impact of technical barriers to trade. J. Policy Model. 34 (3), 497-511.

Maertens, M., Swinnen, J.F.M., 2009. Trade, standards, and poverty: evidence from Senegal. World Dev. 37 (1), 161-178.

Olper, A., Raimondi, V., 2008. Market access asymmetry in food trade. Rev. World Econ. 144 (3), 509-537.
Shepherd, B.,2007. Product standards, harmonization, and trade: evidence from the extensive margin. In: Policy Research Working Papers, No. 4390. World Bank, Washington, DC

Shepherd, B., Wilson, N., 2013. Product standards and developing country agricultural exports: the case of the European Union. Food Policy 42, 1-10.

Swann, G.P., 2010. International standards and trade: a review of the empirical literature. In: OECD Trade Policy Working Papers, No. 97.

Swinnen, J.F.M. (Ed.), 2007. Global Supply Chains, Standards and the Poor. CAB International.

Swinnen, J.F.M., Vandemoortele, T., 2011. Trade and the political economy of food standards. J. Agric. Econ. 62 (2), 259-280.

Vigani, M., Raimondi, V., Olper, A., 2012. International trade and endogenous standards: the case of GMO regulations. World Trade Rev. 11 (3), 415-437. 